\title{
ESPECTROS E CORPOS FEMININOS: GRITOS DA NOITE
}

\author{
SPECTERS AND FEMALE BODIES: NIGHT SCREAMS
}

\begin{abstract}
RESUMO
O presente texto é tecido a partir de uma trama onde se insinuam sucessivamente a noite, a escuridão, inúmeros e provocadores espectros, além dos historicamente excluídos e relegados à dimensão das trevas - as mulheres, os animais, seus híbridos - e as quase sempre estranhas dimensões da arte e da literatura, espaços permissivos a seus ecos. Buscamos imagens na escrita de uma autora contemporânea, Clarice Lispector, e as cotejamos com pinturas surrealistas, de André Bresson e Salvador Dalí, constituindo um conjunto de espectros que motivaram pensamentos sobre a espectrologia derridiana e sobre princípios de exclusão que perdem força diante do contorno da metafísica da presença, permitindo ver nas expressões do noturno no gótico uma positivação das potências orgânicas do feminino e do animal.
\end{abstract}

Palavras-chave: Espectros. Mulher. Animal. Noite.

\section{ABSTRACT}

This text is produced from the connection of the themes: the night, the darkness, countless and provocative specters, in addition to those historically excluded and relegated to the dimension of darkness - women, animals, their hybrids - and the dimensions of art and literature, spaces permissive to their echoes. We searched for images in the writing of Clarice Lispector and in the surrealist paintings by André Bresson and Salvador Dalí, constituting a set of spectra that motivated thoughts about Derrida's spectrology and about exclusion principles that lose strength with the suspension of the metaphysics of presence, allowing to see in the expressions of the nocturnal in the Gothic a positivation of the organic powers of the feminine and the animal.

Keywords: Specters. Woman. Animal. Night.

\section{Introdução}

É o mínimo que posso fazer da minha vida: aceitar comiseravelmente o sacrifício da noite (Lispector, 1998: 39).

Andreia Aparecida Marin

Universidade Federal do Triângulo Mineiro (UFTM). E-mail: aamarinea@gmail.com

Marcos Câmara de Castro

Universidade de São Paulo (USP). E-mail: mcamara@usp.br 
Há determinados temas que não permitem serem anunciados sem que carreguem uma atmosfera de indefinições que torna qualquer tipo de exploração um emaranhado de pensamentos disjuntivos. Iniciamos com essa consideração porque o exercício dessa escrita foi um ato experimental de materialização de um encadeamento de ideias inaugurado em uma dessas temáticas. $\mathrm{O}$ tema desafiador: o feminino e o noturno, especialmente expresso no movimento gótico. A atmosfera que, diante dele, se constituiu: uma trama onde se insinuavam sucessivamente a noite, a escuridão, inúmeros e provocadores espectros, além dos historicamente excluídos e relegados à dimensão das trevas - as mulheres, os animais, seus híbridos - e, obviamente, as quase sempre estranhas dimensões da arte e da literatura, espaços permissivos a seus ecos.

A noite resiste a aprisionamentos porque comporta muitas forças espectrais que se somam e potencializam seus movimentos de ruptura. Na noite, não há qualquer tido de solidez amparada em uma percepção visual, sempre atrelado ao uso da razão. A mulher e o animal foram destinados, histórica e imaginariamente, à noite. São habitantes do fora, mas nos limites de uma exterioridade marcada pela obscuridade, pela indeterminação, pela ambiguidade. Há algo, em ambos, que comunga com os instintos, a magia, inacessíveis e não redutíveis ao logos.

Como seres da noite, guardam um mistério, uma sedução, um risco. É nesse sentido que, ao falarmos dos limites que se pretendeu estabelecer para a noite, estaremos falando também da contenção da mulher. Não é precipitado antecipar que a mulher foi segregada na humanização grega, tendo sido alvo do moralismo platônico e socrático. Foi também submetida ao controle e ao moralismo medievos. Muito dos resquícios desse moralismo perdura, imponente, até a contemporaneidade. Foi nos domínios da noite onde foram encarceradas, que ambas, mulher e animal, encontraram algum sopro de vitalidade. É de lá que ressurgem, potentes e ousadamente visíveis, em nossos dias.

Diante desse cenário complexo e não regulado por oposições binárias simplistas, não foi tarefa fácil escolher o ponto de partida, que ora se colocava claramente nas margens de uma abordagem teórica da dimensão noturna, ora se aproximava de imagens espectrais copresentes. Exigia-se, portanto, uma opção claramente colocada e aceitamos seguir o rastro dessas imagens, a partir do qual a própria estrutura do texto foi sendo tecida.

As imagens que buscamos, na escrita de uma autora contemporânea, cotejada com pinturas surrealistas, constituem um conjunto de espectros que, no lugar se tornarem alvo de uma análise objetivante, motivaram pensamentos sobre a espectrologia derridiana e sobre princípios de exclusão que perdem força diante do contorno da metafísica da presença, permitindo ver nas expressões do gótico uma positivação das potências orgânicas do feminino e do animal.

Na escrita de Clarice Lispector encontramos os motivos da noite e a denúncia de uma condenação de suas indeterminações, ao passo em que o eu narrativo luta por legitimar uma vida sem certezas, próxima dos animais e das feiticeiras... Nas pinturas surrealistas, de Masson e Dalí, diferentes aparições da rediviva Gradiva, 
cuja imagem inaugural remonta ao século II esculpida em pedra, motivo retomado na literatura de Jensen, nas análises psicanalíticas freudianas e em considerações filosóficas de Derrida. Esperamos com essas rememorações, colocar em destaque a ideia de uma espectrologia como fissura da lógica excludente, que enfraqueceu e vitimizou as mulheres na cultura moralista cristã, e a literatura gótica como espaço de legitimação do noturno e de reparação dos efeitos da exclusão.

\section{O incorpóreo: corpo-a-corpo}

“... Na tela fixo o incorpóreo, eu corpo-a-corpo comigo mesma. Não se compreende música: ouve-se" (Lispector, 1998: 10).

Iniciemos com Clarice e sua inquietante obra Água viva. A voz que fala na narrativa é um eu, declinado no feminino, que pinta, escreve e, na maior parte do tempo, está imerso na escuridão da noite ou na presença de animais e de palavras. Não há nome para esse eu, o que sinaliza sua marca de ruptura, desconectando-o de uma forma de dominação que é o ser nomeado como força constituinte. Em vários momentos da narrativa, temos a impressão de que seus pés desenham um rastro movimentado por uma força espectral. É dessa mesma fêmea o estranho ato de comer a própria placenta ${ }^{1}$ e de ter a existência alimentada por fantasmas e indeterminações. No âmbito desta escrita, ousaremos batizá-la de Eu-Gradiva, de Água viva, por motivos que se tornarão claros no avançado do texto, e com a cautela de adotar um termo povoado de múltiplas e indiscerníveis formas.

Paisagem frequentada por Eu-Gradiva, de Água viva, e estampada em suas telas: grutas escuras e perigosas, cheias de névoas, obscuras, compartilhadas com bichos de natureza maléfica:

E se muitas vezes pinto grutas é que elas são o meu mergulho na terra, escuras mas nimbadas de claridade, e eu, sangue da natureza - grutas extravagantes e perigosas, talismã da Terra, onde se unem estalactites, fósseis e pedras, e onde os bichos que são doidos pela sua própria natureza maléfica procuram refúgio. As grutas são o meu inferno. Gruta sempre sonhadora com suas névoas, lembrança ou saudade? espantosa, espantosa, esotérica, esverdeada pelo limo do tempo (Lispector, 1998: 15).

\footnotetext{
1 Referência à resistência obtida pela gata que, "depois de parir come a própria placenta e durante quatro dias não come mais" (Lispector, 1998:31). A autora volta a usar a imagem na sequência: "Falando em segundos pergunto se você aguenta que o tempo seja hoje e agora e já. Eu aguento porque comi a própria placenta (Lispector, 1998: 35).
} 
Nelas, divide espaço com "ratos com asas em forma de cruz dos morcegos", aranhas "penugentas e negras", ratazanas, escorpiões e caranguejos, baratas velhas, formas de vida com as quais seu próprio espectro se identifica: "e tudo isso sou eu"... De fora, "cavalos soltos a patearem com cascos secos as trevas, e do atrito dos cascos o júbilo libera centelhas: eis-me, eu e a gruta, no tempo que nos apodrecerá" (Lispector, 1998: 15). Não seria tão simples para alguém que não admitisse um ser povoado por fantasmas frequentar essa caverna de terror e das maravilhas, lugar de almas aflitas. Só um ser assim poderia desejar intimamente a noite: "a noite de hoje me olha com entorpecimento, azinhavre e visco. Quero dentro dessa noite que é mais longe que a vida, quero, dentro dessa noite, vida crua e sangrenta cheia de saliva" (Lispector, 1998: 25). E reforça sua preferência pelas potências noturnas: "a escuridão é meu caldo de cultura. A escuridão feérica" (Lispector, 1998: 28).

Aqui frisamos a diferença inconciliável da Gradiva do romance de Jensen e da Eu-Gradiva de Água viva: a primeira habitava as ruínas e aparecida ao meio-dia, enquanto a segunda habita a noite, a escuridão. Jamais se saberá, no entanto, onde Gradiva de Jensen passava suas noites, antes de circular, corpórea e luminosa, os caminhos da provocação diurna. Se há um sentido passível de ser descoberto pelas insistências arqueológicas, em arquivos colocados à luz do meio-dia, em Água viva, ele apenas se insinuaria, amplo em seu mistério, na fantasmagórica escuridão da noite: "na minha noite idolatro o sentido secreto do mundo. Boca e língua. E um cavalo solto de uma força livre. Guardo-lhe o casco em amoroso fetichismo. Na minha funda noite sopra um louco vento que me traz fiapos de gritos" (Lispector, 1998: 38).

Não há qualquer compromisso de Eu-Gradiva com as verdades arquivadas em domínios suscetíveis à desocultação: "não quero ter a terrível limitação de quem vive apenas do que é passível de fazer sentido. Eu não: quero é uma verdade inventada” (Lispector, 1998: 22). Prefere evitar ser ofuscada pela luminosidade das elucidações: "vivo de um segredo que se irradia em raios luminosos que me ofuscariam se eu não os cobrisse com um manto pesado de falsas certezas" (Lispector, 1998: 45).

Falemos, pela naturalidade pulsante da narrativa, de uma possível analogia. A habitante da noite de Água viva não quer ser "engavetada na parede" por não ter mais lugar na terra: "inventaram essas diabólicas paredes onde se fica como em um arquivo" (Lispector, 1998: 46). Nenhuma redução da existência em verdades cavadas em alguma ruína, algum recanto de recalques, rememorações. Nenhum corpo consumando o fetiche do arquivamento. Uma existência noturna, povoada por fantasmagorias, de fato, não combina com qualquer simbolismo de enclausuramento. Isso nos dá a tentação de um salto quase inevitável para a ideia de mal de arquivo em Derrida, que exploraremos na sequência.

Há sobre a Gradiva de Água Viva uma "pesada ancestralidade" (Lispector, 1998: 17): "tenho o misticismo das trevas de um passado remoto" (Lispector, 1998: 38). Essa ancestralidade leva-a para aquém e além de sua própria história, fazendo-a transfigurar a realidade, de forma que "outra realidade sonhadora e sonâmbula" a recria (Lispector, 1998: 22). Os espectros movimentam essa transfiguração: "sou 
assombrada pelos meus fantasmas, pelo que é mítico, fantástico e gigantesco: a vida é sobrenatural" (Lispector, 1998: 29). Curiosamente, imediatamente após afirmar essa dimensão espectral, volta à encarnação, conciliando corpo e espectralidade: "vejo a fúria dos impulsos viscerais: vísceras torturadas me guiam” (Lispector, 1998: 29).

Identifica-se com as bruxas e feiticeiras, cujos espectros liberados na fogueira inquisitorial povoam sua existência: "aqueles que nos temem e à nossa alquimia desnudavam feiticeiras e magos em busca da marca recôndita que era quase sempre encontrada embora só se soubesse dela pelo olhar pois esta marca era indescritível e impronunciável mesmo no negrume de uma Idade Média”. Sobre esses reavivamentos fantasmagóricos, acrescenta: "saio dessas torturas de vítima com a marca indescritível que simboliza a vida. [...] Na minha sanha faço a oferenda da alma no seu próprio negrume" (Lispector, 1998: 38).

Quando assim, próxima dos animais, das bruxas e feiticeiras, dos habitantes das grutas escuras, vive pulsátil, sem qualquer interesse nas verdades sobre a vida, é tomada pela força da noite:

Mas esses dias de alto verão de danação sopram-me a necessidade de renúncia. Renuncio a ter um significado, e então o doce e doloroso quebranto me toma. [...] Navego na minha galera que arrosta os ventos de um verão enfeitiçado. Folhas esmagadas me lembram o chão da infância. A mão verde e os seios de ouro - é assim que pinto a marca de Satã" (Lispector, 1998: 26).

Seios e ouro para pintar a marca de Satã. Não parece trivial para alguém que, ao escolher a escuridão como habitat, já havia se identificado com as potências orgânicas dos animais: "nesse âmago tenho a estranha impressão de que não pertenço ao gênero humano" (Lispector, 1998: 29). A visão demoníaca da mulher, tão fortemente alimentada no medievo, fortalecida por um sem número de representações de hibridismos humano-animal, é a marca de uma herança que, muito dificilmente, será extirpada do pensamento ocidental. O que notamos aqui é uma mulher cuja existência é obviamente marcada por esses espectros gestados durante séculos a partir de um princípio de exclusão que coloca tudo aquilo julgado como não plenamente humano nas margens do dia ou soterrados na dimensão noturna. É esse princípio de exclusão sofrido por animais, mulheres, demônios, teromorfos, gárgulas, que sustenta e alimenta a força solidária dos habitantes da noite que retornam insistentemente na história, povoando existências e ganhando legitimidade na literatura e nas artes.

A cada vez que o tema do noturno é acionado, espectros adjacentes ressurgem como que movimentados pelas mesmas forças. $\mathrm{O}$ feminino, a animalidade, a figura satânica, em suas múltiplas formas, compõem sempre traços de espectralidade associados à noite. As artes contemporâneas, em consonância com as forças indeterminantes desse movimento imaginário, acabam por dar visibilidades a essa presença-ausência dos espectros. O surrealismo, o expressionismo, a música contemporânea são permissivos desse jogo da espectralidade. 
A mulher de Água viva, que ouve música com o tato, sentido a vibração da eletrola, esquivando-se de toda tendência ao mal de arquivo, poderia bem ouvir Gradiva de Paul Méfano ${ }^{2}$ enquanto pensa e escreve, emergindo da escuridão de um quarto iluminado pela lua cheia, vendo o vento desenhar, com o movimento das árvores, uma atmosfera fantasmagórica, na qual se sente perfeitamente acolhida e capturada. Ou qualquer outra música que não amarrasse seus pensamentos e sensações na trama dos sentidos estritos:

"a dissonância me é harmoniosa. A melodia por vezes me cansa. E também o 'leitmotiv'. Quero na música e no que te escrevo e o no que pinto, quero traços geométricos que se cruzam no ar e formam uma desarmonia que eu entendo" (Lispector, 1998: 66).

Gradiva, de Méfano, parece também constituída nas incertezas da noite que tanto lhe atraem: a mesma sucessão de presenças-ausências, uma certa imaterialidade que se insinua em espaços de silêncio rasgados por sonoridades descomprometidas com um tempo metrificado, a atmosfera sombria própria aos seres redivivos. Perturbações sucessivas se adensam, como as fissuras das paredes das ruínas pompeianas por onde espectros, como Gradiva, podem surgir ou se ocultar. A materialidade dos sons abrindo espaço para a realidade imaterial. Esse tipo de matéria musical, avessa à clareza das harmonias diurnas, cria a ambiência desses ressurgimentos potentes, invasivos. Noite, mulher e música se positivam em nossos imaginários, em nossas percepções e incorporam-se nos textos, nas sonoridades, nas imagens, nos modos de viver e de estar no mundo.

\section{Gradiva e suas múltiplas transmutações}

De todas as aparições pictóricas que nos ocorreram, a que mais impregnou a tessitura da escrita foi uma gestada no século II d.C. e recorrentemente transmutada, configurando um rastro fantasmagórico explorado até a contemporaneidade. Difícil encontrar justificativas claras para a força dessa imagem que se apresenta sobre as mais variadas formas, alimentando tanto o pensamento filosófico e psicanalítico, como expressões artísticas e literárias. Colocamo-nos atrás de seu rastro por nele vislumbrar um caráter espectral impressionantemente persistente. De Gradiva, imagem de mulher esculpida em uma rocha no II d.C ${ }^{3}$, que muitos querem ler como uma ninfa, dentre tantas que se seguiram, passando pela imagem fantasmagórica que se confunde com uma mulher real na alucinação de um antropólogo, na escrita

2 Gradiva étambém título de uma obra composta para flauta octobasse, em 1978, pelo compositor francês, nascido em Basora, Iraque (1937). Disponível em: https://www.youtube.com/watch?v=3BJvoI3qCow.

3 Imagem disponível em: http://www.museivaticani.va/content/museivaticani/en/collezioni/musei/ museo-chiaramonti/gradiva.html. 
literária de Jensen (1903), pela sua interpretação no substrato do pensamento psicanalítico de Freud (1907), chegamos às provocações surrealistas, na pintura.

Gradiva ressurge em várias partes do mundo e nas mais inesperadas materializações. Se, de um lado, nas construções literárias e nas explorações filosóficas e psicanalíticas, ela aparece como objeto, quase sempre gravitando em um mundo do qual não é o centro e nem o ponto ativo, na pintura ela é mesmo o sujeito que reúne em torno de si todo acontecimento. A Gradiva de Dalí ${ }^{4}$ é plena ação em uma ambiência estagnada, o que nos fez iniciar nosso caminho de ressurgências a partir de sua espectralidade. Haverá, portanto, uma tensão persistente no texto: o conflito entre uma representação de Gradiva associada à mulher como objeto, estagnada, e outra como agente, resguardando a sugestão de movimento da imagem. De acordo com Chadwick (1970: 419), a imagem de Gradiva não pode ser limitada ao conceito tradicional de musa, o que se revela, por exemplo, nas pinturas de Dalí, onde funciona como um poderoso símbolo erótico.

Iniciemos com Gradiva de Dalí, que nos dá a pensar a relação entre corpo e espectro, e avancemos para a Gradiva de Masson5, cuja motivo se desloca para a dualidade vida e morte.

Materialização de Gradiva pelas mãos de Salvador Dalí: Gradiva rediscovers the Antrhropomorphic Ruins (Retrospective Fantasy), 1932. Na apresentação da obra de Dalí, no sítio do Museu Nacional Nacional Thyssen-Bornemisza, Paloma Alarcó descreve duas figuras trancadas em um abraço entre as ruínas de uma paisagem deserta e fantasmagórica, citando uma interpretação sugerida por William Jeffett, segundo a qual existiriam, na tela, duas representações, uma Gradiva real, a outra que está enterrada nas memórias do jovem Hanold (Alarcó, 2019).

Façamos uma breve retomada das ressonâncias de Gradiva em Jensen e Freud. No romance de Jensen, Gradiva: uma fantasia pompeiana, há um jogo entre a imagem e a realidade, na atmosfera alucinatória do arqueólogo Hanold. Após notar a imagem de Gradiva esculpida em alto relevo, réplica da obra do século II, em sonho, Hanold visualizara a morte de Gradiva e seu soterramento nas cinzas de Pompeia. Inaugura, motivado por essa imagem, uma busca arqueológica nas ruínas, onde se espanta com a visão de uma mulher que associa ao fantasma de Gradiva, descobrindo posteriormente se tratar de uma mulher real, Zoe, amiga de infância, por quem nutria sentimentos reprimidos. Na análise de Freud, em O delírio e os sonhos na "Gradiva” de $W$. Jensen, ganha foco o fetiche de Hanold associado à imagem, pela vinculação com a lembrança dessa figura feminina da infância, movimentada por recalques. Em ambas as abordagens, Gradiva gravita em torno dos acontecimentos da narrativa ou como objeto em análise. Na dicotomia típica dos dois textos - material ou fruto de alucinação, real ou espectral —, é sempre na direção da visada masculina e da existência de Hanold que a figura feminina se encaminha. Não se trata da vida, do

4 Imagem disponível em: https://www.museothyssen.org/en/collection/artists/dali-salvador/gradivarediscovers-anthropomorphic-ruins-retrospective-fantasy

5 Imagem disponível em: https://extensao.cecierj.edu.br/material_didatico/artc17o1/galeria_Masson. html. 
movimento, da ação de Gradiva, mas do que sua vida, ou morte, e a delicadeza de seus gestos podem significar para o contorno da alucinação de Hanold ou para a síntese psicanalítica que lhe dê sentido.

Essa centralidade da mulher, ignorada pela narrativa e pelo texto analítico, foi discutida por Tiburi (2012: 446). A autora denuncia nos discursos de Jensen e Freud um traço paternalista na tomada de Gradiva como imagem de uma ninfa, que reforça a idealização das mulheres por interesse do patriarcado: "mulheres que são muito mais imagens e muito menos corpo na cultura que mascara o desprezo pelo corpo na ideologia do culto do corpo" (Tiburi, 2012: 422). Haveria, nas análises freudianas, a perda do caráter concreto, histórico da imagem. A vida nua, que a autora resgata do pensamento de Agamben, seria a que fica no rastro da imagem (Tiburi, 2012: 431). As visões que Hanold julga ter do fantasma de Gradiva apontam para essa idealização da mulher que só sofrerá uma síntese materializante no determinado momento em que ele passa a poder tocá-la.

Indo de encontro a essa centralidade da figura feminina, poderíamos considerar que, para além da interpretação sugerida por William Jeffett, há uma feminina Gradiva que age, persistindo no tempo, em meio às ruínas, e reencontra o ser antropomórfico corroído pelas marcas do tempo, na atualidade da sua condição espectral. Será preciso que contornemos a oposição binária entre real e espectral para que avancemos no desafio de falar do espectro, inevitavelmente híbrido, como redivivo, com existência inquestionável.

O interesse que movimenta a idealização ganha reforço no potencial imaginário associado à morte e às imagens fantasmagóricas, sendo as ninfas, geralmente, mortas e redivivas. A imagem que sugere movimento, como a de Gradiva, seria a manifestação da relação entre vida e morte, sendo a mulher em trajes esvoaçantes que adoece e morre a tônica da composição poética, deixando visível essa potência fantasmagórica (Tiburi, 2012: 435): "a idealização e a morte se confundem porque ambas permitem que a mulher seja uma imagem e não uma realidade incômoda" (Tiburi, 2012: 443).

Dalí, influenciado pela psicanálise freudiana, valoriza a dimensão não material, dos sonhos e alucinações, produzindo a partir do seu método crítico paranoico, imagens permissivas a duplas representações. As ruínas antropomórficas sugerem a atmosfera espectral onde Gradiva é, ao mesmo tempo, morta e rediviva, matéria e espectro. De outra perspectiva, e poderíamos imaginar a da própria Gradiva, a imagem poderia sugerir sua própria materialidade diante de um mundo pleno de presenças espectrais.

As ruínas onde se apresenta Gradiva rediviva, no romance de Jensen e na alucinação pictórica de Dalí, apontam para um tempo onde não estão mais encadeados presente, passado e futuro. Sobre esse tempo redimensionado, Dias (2017: 49) considera: "quando o fantasma entra em cena, seu aparecimento não pertence mais a esse tempo e, portanto, estamos diante de um tempo fora do eixo, para além do presente vivo". 
Vida e morte sobrepostos embaralham, portanto, a lógica do tempo. É justamente essa confusão que podemos encontrar na Gradiva de Masson.

André Masson, a partir de 1929, toma os mitos da Grécia antiga como tema e suas pinturas refletem o caos, a violência erótica e a metamorfose (Chadwick, 1970: 415). Os mitos tornaram-se, para ele, imagens não limitadas à lógica do espaçotempo, retratando um mundo em constante fluxo. Gradiva, pintado em 1939, obedece à ruptura dessa lógica e oferece um retrato inquietante da condição humana. Na descrição de Chadwick (1970: 415): a pintura mostra uma mulher enorme, metade viva, metade petrificada, esparramada em um pedestal de mármore em uma atitude incerta entre sono e morte; as pernas abertas revelam um pedaço de carne e uma vagina disposta como uma concha; as duas metades da mulher são unidas pela continuidade do mármore e a perna carnuda; toda tela é banhada por uma luz avermelhada tremeluzente e aponta para a conjugação de uma dualidade:

Metade de seu corpo classicamente coberto e com sandálias, já se converteu em mármore; o restante ainda é carne, mas a palidez do rosto e do braço direito sugere que o processo de metamorfose não tenha terminado, e que a vida entre a carne viva e o mármore morto é fluida (Chadwick, 1970: 422).

Ainda que extraída da literatura de Jensen, a iconografia de Masson é, segundo Chadwick (1970: 422), mais que uma tradução da sua fonte, revelando adaptações sutis na forma de posicionamento das imagens que sugerem um outro nível de significações: "implícito na pintura está o conceito de destruição holocaustal, cujas fontes podem ser naturais, como o vulcão, ou humanas, como a guerra”. Gradiva sofre ambas as forças destrutivas, estando estampados na tela o vulcão e um rifle, que formam imagens que rodeiam o lugar central da ocupado por uma vagina em forma de concha. Além desses objetos, aparece centralmente um pedaço de carne e um ninho de abelhas, elementos associados à dimensão orgânica. De acordo com Chadwick (1970: 422), o erotismo, a fertilidade e a morte são sempre coexistentes nas obras de Masson. Vale, nesse contexto, voltar ao Eu-Gradiva de Água viva: "vou embora - diz a morte sem acrescentar que me leva consigo. E estremeço em respiração arfante por ter que acompanhá-la. Eu sou a morte. É nesse meu ser mesmo que se dá a morte - como te explicar? É uma morte sensual..." (Lispector, 1998: 26).

Os pés da Gradiva de Masson ganham destaque ainda mais importante do que a Gradiva do relevo e de Jensen. Um deles está estagnado, como mármore, ocupando desproporcional espaço na parte direita da tela. O outro está vivo e indica movimento, como a Gradiva do relevo antigo. Como nas imagens produzidas por Dalí, em Masson, a dimensão viva, biológica, e a mítica estão presentes, em uma combinação transgressora da forma adequada a uma ideia convencional de espaçotempo. Essas condições são justificadas pela influência do pensamento freudiano sobre o inconsciente sofrida pelos surrealistas, entre 1929 e 1930. Em Dalí, há uma composição entre vida e espectro que expressa a natureza dual de Gradiva. Em 
Masson, é o contraste entre vida e morte, animado e inanimado, corpo e mármore, que reforça essa complexidade. De acordo com Chadwick (1970: 419), Gradiva, nome traduzível para "aquela que avança", é um ser atemporal que motiva o artista "em sua incessante tentativa de vislumbrar o que está por vir, além do real". Nessas expressões da arte surrealista, o mundo da imaginação é tão objetivamente evidente como o mundo da realidade fenomenal (Chadwick, 1970: 420).

O tempo e a forma humana desfigurada, estampados em Gradiva de Masson, apontam para a metamorfose entre morte e vida. Estão presentes elementos que desenham uma dimensão sombria, onde essas dualidades são melhor percebidas: luz e escuridão, vida e morte, carne e pedra. Segundo Ries (2002: s/p), "a figura humana está morta e viva, implicando a obsessão de Masson pela morte e pela cultura que existe após a guerra”. Vale destacar que o artista sofrera os horrores da primeira guerra mundial, ocasião em que fora gravemente ferido.

Haddock-Lobo (2015), comentando o texto Espectros de Marx, de Derrida, destaca que a tematização da relação entre vida e morte constrói-se em torno da herança fantasmática: "só se aprende a viver (o que significaria necessariamente aprender a morrer) com os fantasmas" e "estar-com" essa forma de alteridade radical inaugura uma política da herança, da memória, uma vez que "gerações de fantasmas" rompem com a temporalidade e com qualquer possibilidade de metafísica da presença, pois nunca estão presentes ou "presentemente vivos" (Haddock-Lobo, 2015: 558).

\section{Fantasmas não morrem}

Segundo Derrida (2012: 113), para Freud, há uma verdade do delírio, uma verdade da loucura ou da obsessão. Freud distingue verdade histórica de verdade material. Há uma verdade que permanece recalcada no delírio: "a verdade é espectral, fantasmática, eis aí sua parte de verdade irredutível à explicação”.

Derrida considera que o pensamento freudiano tem o mérito de não negligenciar a espectralidade, os fantasmas e assombrações, mas ao tentar dar conta deles de modo positivo, tentou conjurá-los. Se leva em conta os fantasmas, é para dar conta deles, explicar e reduzir a crença neles (Derrida, 2001: 122).

Ao buscar um exemplo para isso que considerava um mal de arquivo, optou justamente pela imagem de Gradiva na paisagem pompeiana. Tal imagem não está acessível a qualquer síntese, ainda que Freud pense chegar a um espectro da verdade recalcado na análise da obsessão: "daí a promessa arqueológica de um retorno à realidade, aqui no caso a efetividade originária de um solo de percepção imediata" (Derrida, 2001: 122).

Foi com essa disposição que julgou acessar, a partir de uma experiência pessoal, a origem de sua própria alucinação. Freud reconheceu experimentar uma alucinação furtiva, percebendo-se diante de um fantasma: a imagem de uma paciente morta que ressurge no corpo de sua irmã, que o procura em seu consultório. Com 
a afirmação dessa experiência, Freud deixara clara a possibilidade de um "arquivo hipomnésico" que não se reduz à memória, "nem à memória como reserva consciente nem como rememoração” (Derrida, 2001: 119). A esse respeito, Solis (2014: 380), comenta que um arquivo "não se reduz a um depósito de memórias sem rasuras, não lacunar, sem esquecimento, bastando acioná-lo para que todas as representações ali guardadas possam vir à tona”. Não é apenas referência temporal a um registro do passado, não sendo reflexo de uma experiência histórica. $\mathrm{O}$ arquivo existe somente no "deslocamento que permite repetição, reprodução, reimpressão".

Esse rastro denunciador da busca de uma verdade no delírio levou Freud a reafirmar a conjuração do fato ao arquivo. Para Derrida (2001: 117), esse fato permite considerar que Freud sofreu do mal de arquivo. O suposto arquivo seria o lugar de algo originário disposto a um exercício arqueológico, acessado pela lembrança. Daí a aposta de Jensen na busca do arcaico (arkhé), da origem e do sentido da imagem de Gradiva, nas ruínas de Pompeia. "A estrutura do arquivo é espectral”, nem presente nem ausente, diz Derrida (1994: 110), que acrescenta: "o motivo espectral põe em cena a fissão disseminante que afeta desde o princípio, o princípio arcôntico, o conceito de arquivo e o conceito em geral" (Derrida, 2001: 111).

A espectralidade, portanto, é furtiva ao mal de arquivo, impedindo qualquer síntese reducionista e contrariando a busca das origens.

Estar com mal de arquivo, não pode significar outra coisa que não sofrer de um mal, de uma perturbação ou disso que o nome "mal" poderia nomear. [...] É dirigir-se a ele com um desejo compulsivo, repetitivo e nostálgico, um desejo irreprimível de retorno à origem, [...] uma saudade de casa, uma nostalgia de retorno ao lugar mais arcaico do começo absoluto (Derrida, 2001: 118).

Não se trataria, no entanto, de abandonar os fantasmas na sua inacessibilidade. Trata-se, para Derrida, de uma questão de justiça. Seria preciso "falar do fantasma, até mesmo ao fantasma e com ele, uma vez que nenhuma ética, nenhuma política, revolucionária ou não, parece possível, pensável e justa, sem reconhecer em seu princípio o respeito por esses outros" (Derrida, 1994: 11). Comentando sobre a responsabilidade advinda da espectralidade proposta no pensamento derridiano em Espectros de Marx, Dias (2017: 42) destaca: "Derrida advoga o reconhecimento dos que não estão mais no presente, senão sob a forma de espectros para uma ética possível”, assim como "uma revisão das dívidas históricas e de ações de reparação dessas dívidas".

Um duplo, nem espírito nem corpo ou espírito e corpo, é o que caracteriza o espectro, segundo Derrida (1994: 6). O espectro é um "presente não-presente, um estar-aí de alguém que partiu , sendo, portanto, "alguma coisa que, precisamente, não se conhece", que não se sabe se responde a um nome e a uma essência, "alguma coisa que não pode ser nomeada” (Derrida, 1994: 7). Outra característica do espectro é ver sem ser visto, não estando suscetível à nossa mirada. De acordo com Paz (2017: 
2764), na espectrologia derridiana, do seu lugar impreciso, o espectro não apenas vê sem ser visto, mas se constitui numa fonte de demandas invisíveis, mas prementes, quando não inesquiváveis.

A espectralidade prevê uma "disjunção da temporalidade, cujos recortes temporais e espaciais se fundem entre as heranças e dívidas históricas e o presente vivo", suscitando uma "crítica radical aos limites dicotômicos e totalizantes, desestabilizando reducionismos, essencialismos e conceitos rígidos” (Dias, 2017: 43). O espectro é justamente aquilo que não se deixa dizer por meio de uma metafísica da presença.

\begin{abstract}
O termo "espectros", em Derrida, está ligado à ideia de hantologie, ou espectralogia, que se opõe à ontologia binária do ser, uma das grandes faces do pensamento derridiano. Em Espectros de Marx, a proposta é ir além da ontologia, pensando aquilo que nunca se faz inteiramente presente, mas na forma de rastro. A imagem dessubstancializada é, então, a do espectro. A indecidibilidade derridiana (nem isto, nem aquilo), visa eliminar de vez os binômios metafísicos, e por isso a fantasmologia, que opera nas inconsistências do real, se opõe à ontologia (Dias, 2017: 46).
\end{abstract}

De acordo com Pinto (2015: 18), Espectros de Marx é a obra em que Derrida utiliza de forma mais frequente a expressão hantologie (espectrologia), visando superar a ontologia que afirma o primado do ser e o dualismo ôntico/ontológico. Na busca de uma dimensão dessubstancializada, de uma inconsistência ontológica, a imagem recorrente passa a ser a do espectro, apontando para uma "virtualidade como condição de toda atualização", em uma lógica que supera o substancialismo do materialismo marxista, abrindo espaço para um materialismo imaterial (Pinto Neto, 2015: 119-120), um "modelo de materialismo energético com forças sem presença" (Pinto Neto, 2015: 124).

O espectro reflete a perturbação causada tanto por algo que impede o ver e o saber, quanto por aquela associada aos segredos, à clandestinidade, aos complôs “entre público e privado, entre a família, a sociedade e o Estado" (Derrida, 2001: 117). A respeito da imagem fantasmática de Gradiva, Derrida (2001: 112) considera que a hesitação não oscila entre fantasma e realidade, mas destaca a menção de Freud a um fantasma real, uma pessoa em carne e osso.

A espectrologia derridiana abre espaço para pensar os fantasmas como outros que povoam nossa existência. Alteridade e espectrologia são, nesse sentido, complementares, uma vez que não seria possível isolar de nossa própria subjetivação a presença dos outros que, vivos ou mortos, se atualizam. Paz (2017: 2764) considera, nesse sentido, que: "é no emaranhado constituído pelas infinitas alteridades em suas infinitas implicações mútuas que o motivo das demandas se insinua”. Para Dias (2017: 42), o espectro povoa o si mesmo, suscitando demandas recorrentes, manifestandose em "imagens fantasmagóricas que nos frequentam ou que historicamente nos 
frequentaram". Há fantasmas em "nível econômico, político, social e midiático mundial”. Dias encaminha a finalização dessa reflexão: "Derrida nos alerta que um fantasma não morre nunca e está sempre a retornar...” (Dias, 2017: 41-42).

\section{Ninfas ou bruxas: idealização ou reparação}

Certamente não morreram os fantasmas alimentados da exclusão que perdura durante séculos em nossa cultura ocidental lançando os seres que carregam os traços da vida orgânica longe da visibilidade diurna. Mulheres, animais, judeus, leprosos, identificados a partir de suas marcas biológicas, foram vitimizados por esse princípio moralista, marcados pela associação com forças demoníacas e lançados no submundo noturno.

A figura demoníaca esteve muito associada à potência vital, à perversão da alma imposta pelas pulsões carnais. Ela está muito próxima do devir orgânico que pulsa na animalidade e em tudo que se aloja no limiar entre o humano e o não humano. É quase sempre por uma característica animalesca que a exclusão moralista é executada. São os corpos e seus sinais os alvos do julgamento e punição de mulheres, bruxas e feiticeiros. Ginzburg (2002) nos ajuda a confirmar essa condição com um detalhado estudo sobre as instruções de autoridades religiosas na Idade Média, as sentenças nos casos de feitiçaria e as confissões dos acusados. Nos discursos da época, é recorrente a associação da feitiçaria com afetos carnais: os acusados comiam, bebiam e defecavam em tonéis, copulavam e dançavam, o que revelava uma humanidade contaminada pelos instintos não mediados dos animais. Essa inclinação para a animalidade era sempre associada a forças demoníacas que desviavam os humanos do controle da razão. Ginzburg destaca, nesse sentido, instruções encaminhadas aos bispos da Igreja em 9o6:

Não se pode negar o fato de que certas mulheres celeradas, transformadas em sequazes de Satã (1 Tim 5,15), seduzidas pelas fantásticas ilusões dos demônios, afirmam cavalgar de noite certos animais junto com Diana, deusa dos pagãos, e com grande quantidade de mulheres, percorrer grandes distâncias no silêncio da noite profunda... (Ginzburg, 2002: 107).

A perseguição histórica dessas sociedades imaginárias de mulheres conduzidas por alguma força demoníaca e associadas aos animais perdurou até o século XV, quando foram relacionadas ao sabá e consideradas crimes passíveis de fogueira (Ginzburg, 2002: 109). Era justamente nos corpos que inquisidores e juízes buscavam os indícios de adesão ao demônio: "procuravam nos corpos dos feiticeiros e das bruxas a prova física do pacto estipulado com o diabo" (Ginzburg, 2002: 91). Lembremo-nos da herança assumida por Eu-Gradiva em Água viva, que denunciava a busca dessa marca indizível no negrume do medievo, só confirmadas pela visão. 
Essas forças demoníacas eram sempre identificadas com uma figura feminina, as deusas da noite, que cooptavam as mulheres. Quase sempre, essas deusas podiam assumir uma forma invisível ou de um animal (Ginzburg, 2002: 122). A espectralidade e a animalidade também eram colocadas em associação no imaginário das mulheres demonizadas: em reuniões noturnas, as mulheres, imitando as deusas que as guiavam, podiam se tornar invisíveis comendo ervas especiais ou transformando-se em animais (Ginzburg, 2002: 92). Entre os séculos XVI e XIX, essa caracterização se repetiu no discurso sobre as "mulheres de fora", que vagavam na noite e podiam ter patas de gato ou cascos equinos (Ginzburg, 2002: 137).

A oposição binária entre diurno e noturno, luz e escuridão, sempre esteve presente nos movimentos de contenção dos instintos animalescos e do devir orgânico feminino. Contra a luz da razão, o moralismo cristão sempre posicionou a invisibilidade e as sombras, habitadas pelas mulheres, especialmente as não contidas nos ritos de sacralização, e pelos animais. Essa oposição também é comentada por Tiburi, ao destacar o momento em que Hanold, no romance de Jensen, nota a imagem da Gradiva esculpida na pedra, guiado por uma luz solar entrando pela janela, em uma espécie de insight: "é por meio desta iluminação, emblemática da razão que percebe as coisas do mundo antes lançadas na sombra, que esta imagem adquire vida. Em termos alegóricos, é como se a razão (do homem) fizesse aparecer a mulher na sombra" (Tiburi, 2012: 433).

É em plena vigência da supremacia da razão, no século XVIII, que a literatura gótica reconduz à visibilidade as monstruosidades e a atmosfera sombria que permanecera contida na noite e na clausura da magia e da escuridão. O período romântico foi permissivo com formas aberrantes e espectrais. Melancolia, morbidez, transgressão marcariam os séculos seguintes, desembocando em uma vasta produção na literatura e na música da contemporaneidade, incluindo o cenário brasileiro. Os monstros e habitantes do noturno não serviriam mais apenas para amedrontar e moralizar os humanos, mas seriam positivados naquilo a ser admitido como parte intrínseca da humanidade.

$\mathrm{O}$ movimento gótico ressurgente no século $\mathrm{XX}$ consolida a inversão da negatividade da imagem feminina associada à escuridão da noite. O noturno se materializa em produções poéticas, artísticas e literárias. O diabólico e o feminino trazem à visibilidade os traços do humano mantidos em regime de ocultação. Os fantasmas gestados no moralismo cristão ressurgem fortalecidos pelas históricas contenções. Os traços da animalidade nas imagens femininas são positivados e os híbridos emergem da escuridão dos submundos como sinais de força e resistência. Há sempre algo de animal no olhar de uma mulher representada por padrões góticos, algo de felino, um olhar de lobo à espreita... Um traço demoníaco, ele mesmo híbrido - animal-homem-demônio - que se dá à visibilidade.

Não obstante, é preciso ainda que continuemos a nos perguntar, em nome da responsabilidade que essa espectralidade nos exige: o que está positivado nesse movimento seria, de fato, a mulher com sua base biológica, seu corpo, sua realidade ou uma imagem transmutada com novos efeitos fetichizantes? Tiburi (2012) havia 
induzido à reflexão sobre essa associação entre negativação do corpo e positivação da imagem nas análises psicanalíticas e filosóficas de Gradiva, resultando uma valorização da imagem da mulher vinculada à idealização das ninfas, das musas, em detrimento da mulher com existência real. É importante que olhemos para o feminino no movimento gótico buscando os sinais de reparação dos rastros de contenção ou a reapresentação de idealizações da mulher.

Czekster (2018:108) destaca a forma como o fantástico, nas suas mais diferentes formas e estilos, "deixou de ser um voo imaginativo sem maiores consequências e passou a constituir um agente de modificação da sociedade”. Inclui nessa condição a "literatura gótica, utilizada como meio de expressão do feminino", especialmente em uma Inglaterra marcada pelo puritanismo e conservadorismo. Segundo ele, a construção estilística das histórias e o ambiente soturno em que elas se desenrolavam permitiam às obras abordarem, por meio da alegoria, assuntos que normalmente seriam vetados pelo mercado editorial da época, como incestos, confinamentos, violências sexuais, amor interacional, repressão sexual e loucura, além de assuntos religiosos e políticos. Nesse contexto, o uso que as autoras encontraram para a literatura gótica foi o de dar voz aos seus anseios até então sufocados, encontrando plena aceitação em meio a um público leitor majoritariamente formado por mulheres (Czekster, 2018: 109).

Esse indicativo reforça a ideia de um abalo nas dinâmicas de poder no espaço contemporâneo, sendo a literatura gótica um dos espaços de escape dos discursos moralistas e das exclusões operadas em nome de uma substancialidade do real. $\mathrm{O}$ movimento gótico traz à tona as criaturas da noite, os espectros, as monstruosidades e fantasmagorias que malogram na busca de sentidos originários do ser e que reafirmam a condição historial do humano. Nesse sentido, exigem a responsabilidade diante de espectros que denunciam uma longa e trágica história de condenação dos corpos femininos e dos animais.

\section{Considerações finais}

Revisitamos, ao longo dessas ideias, alguns espectros femininos na literatura e nas artes. Iniciamos pela obra Água viva, de Clarice Lispector, com o intuito de impulsionar a escrita com a subversiva imagem de sua protagonista, que nos exige colocar em suspensão tanto a busca de uma verdade resguardada em uma origem, uma vez que ela não tem interesse pela existência amparada por sentidos elucidados, quanto a ocultação das potências orgânicas da mulher e do animal.

Lispector (1998) consegue materializar em uma escrita, que ela mesma quis sem compromisso com qualquer sentido, esses traços e suas marcas. Água viva foi a pulsão desses espectros para quem abriu, gentilmente, um amplo caminho. EuGradiva coloca-os diante de nós, entre nós, fazendo jus a uma força durante longo tempo contida em nossa história racional e moralista. Age com a responsabilidade 
sugerida por Derrida, positivando: contra os excludentes, a mulher, o animal, as bruxas; contra os que sofrem mal de arquivo, os sem sentidos, a não-verdade, os que preferem não ter significado; contra os discursos redutores da fluidez, do movimento e da ação de uma mulher, uma Gradiva que anda livre na noite, entre as bestas e os fantasmas, que nunca morrem.

Identificar a protagonista de Água viva com a Gradiva do relevo antigo foi quase inevitável. Tudo pareceu se passar como se os passos sugeridos na Gradiva esculpida provocassem rastros repetidos pela personagem clariceana, marcados pela mesma sutileza de quem, ainda que levitando, deixa marcas reconhecíveis. Ambas guardam a duplicidade real-virtual que se atualiza a cada nova palavra ou a cada novo olhar. Elas são semelhantes na medida em que escapam facilmente dos intentos de Jensen e Freud, contornando, subversivas, análises que as querem gravitando em torno das idealizações masculinas, inativas. Escaparam já, antes disso, de toda intenção de clausura em um significado unívoco. São multiplicidades.

A fêmea de Água viva coloca-se em conivências com demônios, fantasmas, mas também com os instintos animais, em todas as suas formas, e chega a renunciar ao pertencimento a uma plena humanidade. Há algo nela da Gradiva de Dalí, que conjuga espectro e matéria, e de Masson, que confunde passado-presente-futuro, embaralhando a morte e a vida em estranha transmutação.

As três imagens - mulher de Água viva, Gradiva de Dalí e Gradiva Masson -, bem como as sonoridades de Gradiva de Méfano, não são expressões do movimento gótico. No entanto, cada uma delas, a seu modo, trazem à tona a fantasmagoria que é, nele, alvo de tematização: o feminino no gótico. Funcionam como ressonâncias tardias de um grito por justiça, inegavelmente refletidas no gótico. É na literatura e nas artes permissivas às monstruosidades que estão às soltas, aos fantasmas que nunca morrem, que se pode vislumbrar um espaço de reparação das exclusões e vitimizações a que mulheres e animais foram submetidos. Onde a noite ganha legitimidade, os espectros exigem uma nova dimensão de alteridade. Os outros, estranhos ou não, estão aí, a povoarem inevitavelmente aquilo que somos. Terminamos com quem começamos nosso trajeto, com "aquela que avança” em Água viva: "vou adiante de modo intuitivo e sem procurar uma ideia: sou orgânica. E não me indago sobre os meus motivos. [...] sou obscura para mim mesma” (LISPECTOR, 1998, p.23-24).

\section{Referências}

ALARCÓ, Paloma. (2019). Salvador Dalí. Gradiva rediscovers the anthropomorphic ruins. In: https://www.museothyssen.org/en/collection/artists/dali-salvador/ gradiva-rediscovers-anthropomorphic-ruins-retrospective-fantasy, acessado em $17 / 10 / 2019$. 
CHADWICK, Whitney. (1970) Masson's Gradiva: the metamorphosis of a surrealist myth. The Art Bulletin, c.53, n.4, pp.415-422, dez. Disponivel em https://www.jstor. org/stable/3048768. Acessado em 25/10/2019.

CZEKSTER, Gustavo M. (2018). A mulher na narrativa fantástica: um estudo comparativo entre os contos de Horacio Quiroga e Samanta Schweblin. In: Colóquio Sul de Literatura Comparada, 2018. Ilhas Literárias. Estudos de Transárea. Porto Alegre: Editora do Instituto de Letras, v.2, pp.107-115.

DALÍ, Salvador. (1975). Gradiva rediscovers the anthropomorphic ruins (Retrospective Fantasy). Oil on canvas, Museo Nacional Thyssen-Bornemisza, Madrid.

DERRIDA, Jacques. (1994). Espectros de Marx: o estado da dívida, o trabalho do luto e a Nova Internacional. Trad. Anamaria Skinner. Rio de Janeiro: Relume-Dumará.

DERRIDA, Jacques. (2001). Mal de arquivo: uma impressão freudiana. Trad. Claudia M. Rego, Rio de Janeiro: Relume-Dumará.

DIAS, Felicio L. (2017). Espectros de Derrida na ficção brasileira contemporânea: 1964 e seus fantasmas consistentes nas obras A resistência, de Julián Fuks, e Lavora Arcaica, de Raduan Nassar. Cadernos literários, v.25, n.1, pp. 41-52.

GINZBURG, Carlo. (2002). História noturna: decifrando o sabá. Trad. Nilson Moulin. São Paulo: Companhia das Letras.

HADDOCK-LOBO, Rafael. (2015). "Não aprendi dizer adeus”. Educação e Filosofia, v.29, n.58, pp.547-566, jul-dez.

JENSEN, Wilhelm. (1987). Gradiva, uma fantasia pompeiana. Rio de Janeiro: Jorge Zahar.

LISPECTOR, Clarice. (1998). Água viva. Rio de Janeiro: Ed. Rocco.

PAZ, Ravel G. (2017). Pensar as demandas: implicações ético-estéticas da espectrologia de Jacques Derrida nas teorias da narrativa. In: Anais da XV Abralic - Experiências literárias, textualidades contemporâneas, pp.2763-2774. Rio de Janeiro: UERJ.

PINTO Neto, Moysés. (2015). A estranha instituição da literatura no multiverso dos espectros. Alea, Rio de Janeiro, v.17, n.1, pp.114-126, jan-jun.

RIES, Martin. (2002). Andre Masson: surrealism and his discontents. Art Journal, v.61, n.4, pp.74-85. 
SOLIS, Dirce E.N. (2014). Tela desconstrucionista: arquivo e mal de arquivo a partir de Jacques Derrida. Revista Filos. Aurora, Curitiba, v.26, n.38, p.373-389, jan-jun.

TIBURI, Marcia. (2012). Gradiva espectral. Sapere Aude, v.3, n.6, pp.421-454, 2º sem.

Recebido em 08/04/2020.

Aceito em 11/10/2020. 